\title{
Political Stress and the Sustainability of Funded Pension Schemes: Introduction of a Financial Theory
}

\author{
Ishay Wolf
}

check for updates

Citation: Wolf, Ishay. 2021. Political Stress and the Sustainability of Funded Pension Schemes: Introduction of a Financial Theory. Journal of Risk and Financial Management 14: 525. https:// doi.org/10.3390/jrfm14110525

Academic Editor: Shigeyuki Hamori

Received: 29 May 2021

Accepted: 13 July 2021

Published: 3 November 2021

Publisher's Note: MDPI stays neutral with regard to jurisdictional claims in published maps and institutional affiliations.

Copyright: (C) 2021 by the author. Licensee MDPI, Basel, Switzerland. This article is an open access article distributed under the terms and conditions of the Creative Commons Attribution (CC BY) license (https:/ creativecommons.org/licenses/by/ $4.0 /)$.
Faculty of Business Administration, Ono Academic College, Kiryat Ono P.O. Box 759, Israel; ishay.wolf1@gmail.com

\begin{abstract}
This study introduces multiplayer game in the modern pension market. Particularly, this study claims that low earners and high earners have different interests when playing in funded pension market scheme. This differentiating is enabled by avoiding the entire society as a single earning cohort. This study using financial position, demonstrates a socio-economic anomaly in the funded pension system, which is in favor of high-earning cohorts at the expense of low-earning cohorts. This anomaly is realized by a lack of insurance and exposure to financial and systemic risks. Furthermore, the anomaly could lead to a pension re-reform back to an unfunded scheme system, due mostly to political pressure. This study found that a minimum pension guarantee is a rebalance mechanism for this anomaly, which increases the probability of a sustainable pension scheme. Nowadays when countries try to balance between social expenses and awaking financial markets, one may find this theory highly relevant. It is obviously one of the cases where social targets meat financial equilibrium and here they are in the same side. Specifically, it is argued that implementing the guarantee with an intra-generational, risk-sharing mechanism is the most efficient way to reduce the effect of this abnormality.
\end{abstract}

Keywords: defined contribution; pay-as-you-go; put option; social security

JEL Classification: G18; G22; H23; I38

\section{Introduction}

The coronavirus disease (COVID-19) pandemic - and the economic shutdowns imposed to contain the virus' spread-have had disastrous impacts on worldwide economic activity. Amid large-scale unemployment, rates of poverty, hunger and homelessness are on the rise. Workers from marginalized groups have been disproportionately affected, and as economies begin to reopen, the heightened risks of hiring discrimination stemming from the downturn have the potential to widen social gaps further.

Over the last two decades, EU institutions grew more concerned with national retirement systems. Whereas Barr and Diamond (2016) presented sound theoretical arguments detailing why the Maastricht fiscal regime requires convergent and reformed European pension systems, internal market Commissioner Bolkestein gave the rationale for greater intervention in his 2001 speech on defusing the 'pension time bomb'. Still, only with the sovereign debt crisis, external political and market pressures started to outcompete national politics regarding pension-related decisions (Guardiancich and Guidi 2020).

Nowadays the fiscal stress is not the only driver to pension reform, after two economic turmoil in 13 years, risk protection for retirees has become one of the focuses of the debate on how competent retirement systems can be organized (Orenstein 2013). The old question of the extent of funded pension scheme comes again to the headlines in this period of unstable economic landscape. Defined contribution (DC) plans are already the main source of retirement income in Latin American and Central Eastern European (CEE) countries, while it is expanding rapidly in other countries in Western Europe, where they are still voluntary (Grech 2015). Who can guarantee that people save enough for their retirement 
or have enough accumulation to remain their standard of living or at least avoid poverty? The financial crisis in 2008 and current economic downturn raise these questions again.

Correspondently, the vast majority of the literature has observed pressure toward reversals and government insurance in countries which have been through radical funded reforms (Wolf and Caridad y Lopez Del Rio 2021b; Altiparmakov 2018; Naczyk and Domonkos 2016; Orenstein 2013). While the literature still studies the reasons for pension reversals, some scholars argue that the unstable pension landscape is due to a lack of risk-sharing mechanisms in these countries compared to developed countries (Fultz and Hirose 2019; Ebbinghaus 2015). In the period when countries try to engage their economies again after the COVID-19 financial crisis, this paper suggests balancing funded pension schemes that are hedging from market turmoil and increasing trust in the central planning operations. Indeed, according to the recent literature, after the rigmarole of the global experience and the subsequent debates, the implementation of a minimum pension guarantee has become a key recommendation of global economic organizations as part of a modern funded scheme (e.g., Hujo and Ralli 2014).

Using simple financial positions embedded as options, this theory implies a trade-off between accumulation insurance and return in pension design. This perspective enables the classic economic funding condition in Aaron (1966) to be enriched through the dimension of risk. In addition, this perspective on financial standing allows for differentiation in society. This theory shows that disappointment over a funded scheme may come from low-earning cohorts, while high earners will benefit from the transition. After recognizing the gap between financial positions, this paper offers an equilibrium satisfying multi player game by intra-generational risk sharing. Thus, this paper may be included in the literature on risks in pension schemes (Wolf and Caridad y Ocerin 2021; Wolf and Caridad y Lopez Del Rio 2021a; Chen et al. 2014).

In the second part of this paper, the study focuses on the guarantee cost characteristics, boundaries, constraints, and a favorable form of finance.

The next part characterizes different pension systems by the financial instrument of options. Section 3 provides the results of the theoretical model, suggesting a new equation to examine the relevance of pension transition and introducing the minimum pension guarantee as a re-balance instrument that may increase the probability of avoiding cyclical pension reforms. In Section 4, the study discusses the implementation and the main consequences of the results found. Section 5 provides the conclusion.

\section{Theoretical Basis}

\subsection{The Difference between Defined Contribution Pension Scheme and Defined Benefit Pension} Scheme

In this section, the financial positions of different pension schemes are investigated using the exchange option benefit theory.

Along with the defined contribution plan, the pension's value is equal to the individual's accumulations at the time of retirement (Romaniuk 2009). The final amount of the funded capitalized pension fund can be expressed as the function of the funded asset accumulations $\left(A_{T}\right)$ along with the participant's career, during the working phase, capitalized until death:

$$
D C\left(T_{R}\right)=\tau A_{T}=\sum_{t=1}^{T_{R}-1} \tau w_{t} \prod_{t=1}^{T_{D}-1}\left(1+r_{t}\right)
$$

where $r_{t}$ is the average rate of return earned by the DC plan on its portfolio of financial assets at time $t ; T_{R}$ is the participant's retirement year; $T_{D}$ is the average age of death; $t=1$ is the time of enrolment in the pension fund; $T$ is the expected individual's lifetime, as this model avoids actuarial factors related to the probabilities of survival; $w_{t}$ is defined as the equivalent gross earnings at the beginning of each year; and $\tau$ signifies the contribution rate to pension from wage. 
The defined benefit (DB) scheme, however, is the function of the participant's wage, working period, and age. The individual member is paid at the level of the fund obligations independently from market (asset) performance. Hence, intuitively:

$$
D B_{T_{R}}=\tau L_{T_{R}}
$$

where $L_{T}$ is the fund's liabilities. Notably, $C_{L}$ and $P_{L}$ denote the call and put exchange options, respectively, whose pay-offs at retirement are as follows:

$$
\begin{aligned}
& C_{T_{R}}=\max \left(\tau A_{T}-L_{T}, 0\right) \\
& P_{T_{R}}=\max \left(L_{T}-\tau A_{T}, 0\right)
\end{aligned}
$$

The European put option on the fund assets includes liabilities as per the strike price and a maturity corresponding to the retirement date. The put-call parity in future terms is defined as follows:

$$
C_{T_{R}}-P_{T_{R}}=\tau A_{T}-L_{T}
$$

Hence, one can describe the DB scheme as:

$$
D B_{T}=L_{T}=\tau A_{T}+\left(P_{T_{R}}-C_{T_{R}}\right)
$$

The investment in a defined benefit scheme, thus, can be replicated by a position composed of three elements: a long position in the fund assets, $A$, a long put position, $P_{L}$, and a short call position, $C_{L}$, at the same strike price. Figure 1 plots the options value as function of the old age benefit. Consequently, one may point that a defined contribution scheme's benefits are equal to the investment in a defined benefit fund with the buying call option as $C_{L}$ and selling put option as $P_{L}$ at the same strike price:

$$
D C(T)=D B+\left(C_{T_{R}}-P_{T_{R}}\right)
$$

It can be noted that high-earning cohorts or, more precisely, those whose total old-age pension accumulation exceeds the former strike price or the average replacement level $(\bar{W} * R R)$ are expected, on average, to benefit from the transition, as there is no longer a cap on their old-age benefits. In contrast, those whose accumulations are expected to be below this level will be worse off as they are no longer insured by a put option up to a higher benefit level. One can add that low earners have less financial tools and knowledge to hedge their old age accumulation then high earners have.

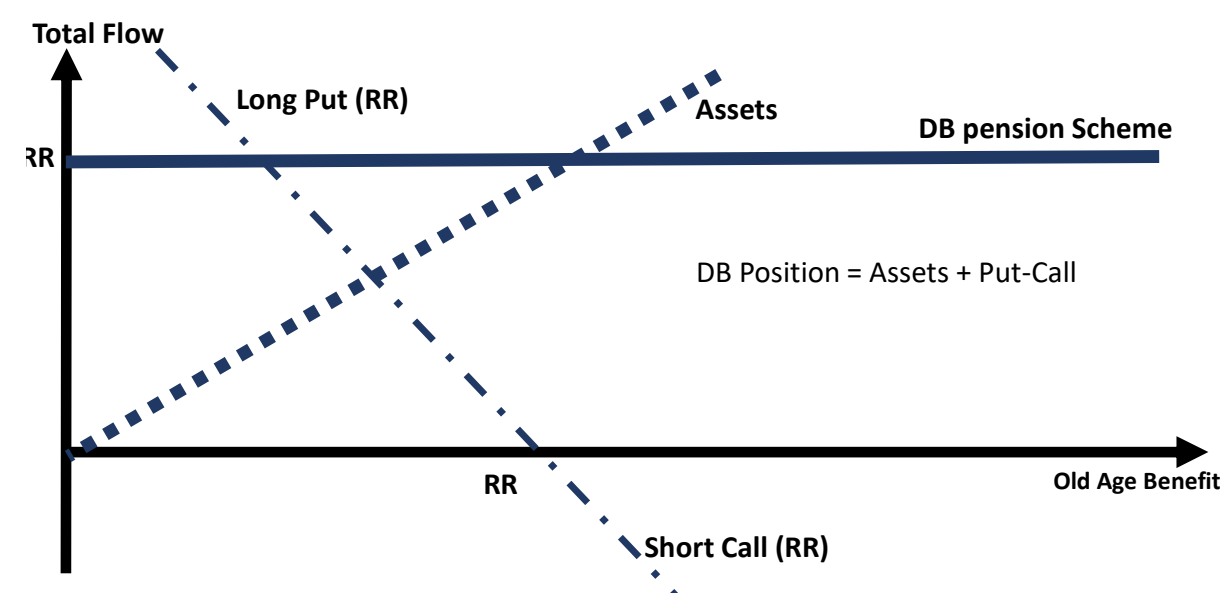

Figure 1. The Put-Call Parity. 


\subsection{Mix Pension Scheme}

In this section, a mix/hybrid pension scheme with two pension pillars is defined: pay-as-you-go (DB PAYG) and funded DC scheme. Here, $\tau$ is the total contribution rate from the participant's wage. The contribution is split into two components: $\gamma$ as the portion of funded DC from the pension contributions, and $(1-\gamma)$ as the contribution share, which finances the DB PAYG.

At retirement, the individual has the benefit position of a hybrid scheme $\left(P N_{T_{R}}^{h y}\right)$ :

$$
P N_{T_{R}}^{h y}=\tau\left\{\gamma A_{T_{R}}+(1-\gamma) L_{T_{R}}\right\}
$$

Integrating (8) with (6) gives the following:

$$
P N_{T_{R}}^{h y}=\tau\left\{\gamma A_{T_{R}}+(1-\gamma)\left(A_{T_{R}}+P_{T_{R}}-C_{T_{R}}\right\}\right.
$$

That can be reduced to the following:

$$
P N_{T_{R}}^{h y}=\tau\left\{A_{T_{R}}+(1-\gamma)\left(P_{T_{R}}-C_{T_{R}}\right)\right\}
$$

From (10), it can be seen that, when the unfunded pillar's contributions are positive, the participant member is willing to pay an insurance premium of $\tau(1-\gamma) C_{L_{T}}$ against the adverse accumulation outcomes on a level of $\tau(1-\gamma) P_{L_{T}}$. Hence, an efficient insurance effect in a hybrid pension scheme, relative to the DC scheme, accrues when:

$$
0<\tau(1-\gamma)<1
$$

After the transition, social security benefits, $L_{T}^{\prime}$, are not correlated any more to the former liabilities level, $L_{T}$. They connect with the new social security contributions level, which is a function of wage level, wage growth rate (marked by $g$ ), and the contribution rate to the first pillar. Equation (10) describes the difference between the two unfunded types of pillar benefits, before and after the pension transition:

$$
\begin{gathered}
L_{T}=\sum_{i=1}^{N} \sum_{t=1}^{T} w_{i, t}(1+g)^{t-1} * R R \\
L_{T}=\sum_{i=1}^{N} \sum_{t=1}^{T} \tau(1-\gamma) w_{i, t}(1+g)^{t-1}(1+n)^{t-1}
\end{gathered}
$$

where $R R$ represents the average replacement rate level of the DB pension scheme. The actual old-age benefit in a mixed scheme with the new social security level can be described as follows:

$$
P N_{T_{R}}^{h y^{\prime}}=\tau \gamma A_{T_{R}}+L^{\prime}{ }_{T}
$$

The difference between the actual benefit after the transition in Equation (14) and the individual's benefit expectation is noted in Equation (15). This difference creates an expectation gap, leading to an anomaly for pension benefits for low-earning cohorts. This theory is discussed in the next subsection.

Continuing to analyze the transition from an individual perspective, the change in the pension benefit at retirement is as follows:

$$
\begin{gathered}
\Delta(\text { Pension Financial Position })=P N_{T_{R}}^{h y^{\prime}}-D B \\
\Delta(\text { Pension Financial Position })=\tau \gamma A_{T_{R}}+L_{T}^{\prime}-L_{T}
\end{gathered}
$$


At the macro-economic level, the government's net flow of old-age social transfers to the public are summed to:

$$
\Delta(\text { Gov. Net Flow })=\text { Expenditures }- \text { Revenues }
$$

- The change in the government's revenues from the transition is: $-\gamma \tau \sum_{i,}^{n+1} w_{t+1}$

- The change in the government's expenditures from the transition is: $L_{T}-L_{T}$

Hence, if the contribution rate is constant during the transition, one can determine the following:

$$
\Delta(\text { Gov. Net Flow })=L^{\prime} T-L_{T}+\gamma \tau \sum_{i=1}^{n+1} w_{t+1}
$$

During the pension reform toward a funded-capitalized design, one can assume that the participants' total benefit from the transition (as described in Equation (16)) is higher than the total government fiscal savings (as described in Equation (18)).

$$
\Delta(\text { Pension Position }) \geq \Delta(\text { Gov. net Expenditures Flow })
$$

Hence,

$$
\begin{gathered}
A\left(T_{R}\right)>\sum_{i=1}^{n+1} w_{t+1} \\
\sum_{i=1}^{N} \sum_{t=1}^{T} W_{i, t}(1+r)^{t-1} \geq \sum_{i}^{n} \sum_{t=1}^{T} W_{i, t}(1+n)^{t-1}(1+g)^{t-1}
\end{gathered}
$$

From the central planner perspective, taking into account the society interests as one unit, the transition is worth it if the following holds:

$$
\sum_{i=1}^{T}(1+r)^{t-1} \geq \sum_{i=1}^{T}(1+n)^{t-1}(1+g)^{t-1}
$$

Equation (22) represents the rationale of pension transitions from the economy level and is similar to the condition in Aaron (1966), which considers the transitioning to the funded scheme from PAYG $(r>n)$. According to the analysis above, the rule is also true for the transition to a mix/hybrid scheme as the condition does not depend on the contribution rates of pension pillars.

Equation (22) corresponds to the former World Bank view and early macro-economic literature on pension reforms in aging economies (Barr and Diamond 2016; Feldstein and Ranguelova 2001), while ignoring risk and individual preference (Holzmann and Hinz 2005). The option model above was utilized to consider the interests of the different actors through their financial position.

\subsection{The Government Perspective}

The government perspective considers two separate interests. Fiscally, as an active actor in the field, the transition to a funded scheme is worthwhile as it liberates the government from the fiscal and longevity burden of risk. These risks are transferred individually or collectively to participants (Barr and Diamond 2016).

From a public perspective, or with the government as a central planner, the transition is worthwhile only if the condition in Equation (19) is valid. In addition, the public perspective might include social targets, such as income redistribution and a reduction of the level of income inequality. These considerations might result in a push for changes in the transition. From both government's perspective, the transition might be worth, unless the market returns are not high enough relative to the government yield. This scenario of un satisfied yield is often related to undeveloped markets with high sovereign credit risk. 


\subsection{The Individual's Perspective}

The individual's financial position after the transition is given by Equation (14). The individual benefits from the transition if:

$$
\tau \gamma A\left(T_{R}\right)+L^{\prime}\left(T_{R}\right)-\left(\tau A\left(T_{R}\right)+P_{T_{R}}-C_{T_{R}}\right)>0
$$

By reducing the total population indexation, one can determine that, on average, the individual participant benefits from the transition if the following is valid:

$$
\tau(1-\gamma) w_{i, t}\left\{\left(1+g_{t}\right)^{t-1}\left(1+n_{t}\right)^{t-1}-\left(1+r_{t}\right)^{t-1}\right\}+C_{T_{R}}-P_{T_{R}}>0
$$

The expression in the large curly brackets is negative, but should be very close to zero as in the long-term: $\left(1+r_{t}\right)^{t-1}=\left(1+g_{t}\right)^{t-1}\left(1+n_{t}\right)^{t-1}$. Consequently, one can determine that the individual benefits from the transition if:

$$
C_{T_{R}}-P_{T_{R}}>0
$$

In that case, only those whose long call option is "in the money" and whose short put option position is "out of the money" will gain from the transition; in absolute terms, their pension accumulation is above the average threshold level $(\bar{W} R R)$. They may gain, on average, from the transition. Hence, the question of the individual's gains from the transition depends on his wage level, along with his career path and the market yield. If the individual's wage is relatively low, they must be extensively exposed to market risk to gain from the transition. Although the compensation for market risk provides an expectedly higher yield than the GDP per capita, participants who are averse to risk might avoid significant exposure to market fluctuations (Wolf and Caridad y Lopez Del Rio 2021b). That tendency is crucial when the individual's accumulations are not high. Even if it is assumed that all the participants share the same risk aversion coefficient, the total risk appetite depends on total accumulations (Nelson et al. 2019)

In further discussion, low and high earners are defined according to the absolute strike price. It can be determined that the pension transition is biased in favor of high earners compared to low earners. The extent of the bias depends on the dispersion of benefits above and below the former strike price. The lower an individual's accumulation is, the worse their financial position would be after the transition, and vice versa.

\section{Minimum Pension Guarantee as a Balance Mechanism}

\subsection{The Demand for Guarantee in Funded Pension Schemes}

For sustainable funded pension design we identify two accumulate conditions. If the average market yield is high enough, according to the condition illustrated in Equation (19), there is a chance of actual transition. However, the sustainability of the transition depends on political pressure. If most people benefit from the transition, according to the condition described in Equation (21), the new system may be sustainable. Alternatively, if a critical mass of participants is worse off after the transition, political pressure might push toward pension reversals (Orenstein 2013; Ebbinghaus 2019).

In an attempt to reduce the probability of pension reversal, governments have an incentive to increase pension accumulations to the lower accumulation distribution tail. If more people benefit from the transition, the probability of keeping the transition sustainable would be higher (Wolf and Caridad y Lopez Del Rio 2021b). That can be achieved by any means of intergenerational risk sharing or financial transfer. The focus on minimum pension guarantee is for calibration these means to a social threshold. To this consideration, one may add public social targets of poverty alleviation and income redistribution. In the Appendix A, we introduce only the most funded markets of pension schemes. According to Mercer report (Mercer Global Pension Index 2021) these funded schemes are high ranked in the list of the best pension systems. The funding for it self does not make the system adequate and sustainable but the balance those countries found. That may include high 
public expenses and implementing minimum pension guarantees in one way or another. According to the OECD reports (OECD 2019), the sustainability of the American and the Israeli pension systems depend in future strengthening these social transfers' mechanisms. Funded schemes with low public pillar are in convergence process toward finding the minimum guarantee, which satisfies critical mass of participants. Over the last decade, the reversal wave in CEE countries and Latin America may reflect the public demand for risk sharing in their pension systems and some protection of benefits (Natali 2018).

In the U.S., U.K., Ireland and Israel, the liberal economy agenda is dominant with minimum government intervention (Giorno and Adda 2016). We believe this agenda has lowered the expectations of benefits, compared to other OECD countries. In addition, in these countries, as the poverty rates and income inequality levels are high, we find it challenging for the government to increase the guarantee levels. Such an increase would be quite expensive according to the above model.

\subsection{The Finance Question}

The central planner may finance the guarantee by increasing the contributions to the working population, and levying the cost on the younger generation, or by financing the same generation (Intra-generational risk sharing). As the financial position of a highearning cohort would be better than a low-earning cohort after the transition, determining an intra-generational compensation (minimum guarantee) would be straightforward. This type of "externalities" solution was discussed in Wolf and Caridad y Lopez Del Rio (2021a), which included welfare and preferences among cohorts.

Naturally, in the era of aging societies, it is not advisable for the market to rely solely on financing by a younger cohort. Economically, it would be efficient for every generation to compensate according to its poverty rate and income dispersion.

\subsection{The Guarantee Cost}

The model presented above implies further characteristics of the minimum pension guarantee mechanism. The guarantee is attributed as a long put option on behalf of the individual. While holding this position, the lower the pension accumulation, the higher the insurance effect. Consequently, the cost of the guarantee is simply the discounted value of the benefits from the option, discounted at the government's risk-free rate (Grande and Visco 2010). An overview of the main parameters influencing the guarantee cost exchange option perspective is as follows.

A. The Underlying Asset

After the transition, the social security pillar and the funded pillar replace the former DB PAYG pension scheme. Hence, the underlying asset is defined the total pension accumulations from both pillars. Consequently, it is argued that any insurance must be examined and related to the overall benefits and in absolute terms. An example of this kind of guarantee relative to total pension accumulation is implemented in Denmark (Jensen et al. 2019). The relative rate of return guarantees, which are implemented widely (Antolín et al. 2011), may provide sufficient protection for some periods, but not against risks such as the market risk of GDP per capita, the labor risk, and the systemic risk. ${ }^{1}$

\section{B. Guarantee Line}

As discussed above, the economic rationale of the guarantee serves the condition in which enough participants must gain from the transition to avoid political pressure for another pension reform (Orenstein 2013). Similar to the put option, when the exercise price is higher, the guarantee cost increases. In the edge case, when the guarantee line is determined at the average "RR" level, the pension system is virtually back to a DB pension scheme. Hence, it is assumed that the exercise price of the guarantee cannot pass that line.

Finding the minimum effective strike price is challenging as it depends on a variety of parameters. Due to social concerns, some countries may mark the poverty line as a minimum that ensures a proper standard of living in old age (Grande and Visco 2010; 
Pennacchi 1999). The poverty line might be high enough to keep the transition sustainable, but it also depends on other variables that change from time to time, such as the dispersion level and the market yield. Hence, it can be claimed that the government must react to macro-economic changes. For example, the permanent reduction in the average rate of return should lead to the consideration of an increase in the strike price of the guarantee.

\section{Pension Pillar Sizes}

Increasing the weight of the funded pillar within the pension system increases the individual's exposure to financial risk. Consequently, two contradictory factors influence the return and risk of the guarantee cost:

- The rate of return of the funded pension: naturally, as the average pension return is higher, there is more probability that the individual's old-age benefit exceeds the guarantee threshold and there are less chances that the put option would be exercised. Hence, intuitively, when the average return is higher, the expected pension guarantee cost is lower.

- The volatility influence: with a higher funded pillar weight, the portfolio accumulation of pension benefits and the standard deviation increases as $\sigma_{A}>\sigma_{W}$. Following the Black-Scholes option pricing model, the volatility of a higher pension portfolio increases the guarantee cost. Hence, the "financial" position of the state, as the writer of the option, is under more stress.

- Naturally, the above conclusions are opposite if the weight of the unfunded pillar increases. Summing the return and the volatility influences, there is no clear conclusion as to whether the guarantee cost will increase when the funded scheme is increased. This is in line with Barr and Diamond (2009), who argued against the pension literature strand during the 1990s, which pushed to implement funded pension funds to decrease fiscal burdens.

D. Market Yields

A higher rate of return, $r$, increases the value of the underlying asset and respectively reduces the put option value/cost. On the other hand, the GDP per capita does not influence the guarantee cost, since both the strike price and the underlying asset are indexed to the GDP per capita.

\section{E. Income Dispersion}

With high-income inequality, statistically, there is a higher probability of individuals' put options to be exercised at retirement. As a consequence, the total guarantee cost in the market will be higher. In a theoretical case where there is a flat dispersion of accumulation around the RR level, flows from high-earning cohorts to low-earning cohorts can imitate the $\mathrm{DB}$ pension scheme, bringing all participants to the RR average point in absolute financial terms. In the common case with income inequality, the burden of the guarantee cost is distributed among fewer participants and, naturally, its exercise price is lower than the average RR level. In Figure 2, in the market B with smoother or equal income distribution than market $\mathrm{A}$, the minimum pension guarantee can be higher, as more participant from high earning cohorts share the finance burden. Alternatively, with moderate distribution, for a given guarantee level, the call strike price can be higher, meaning less participants will share the finance burden. Indeed, 
Population Distribution

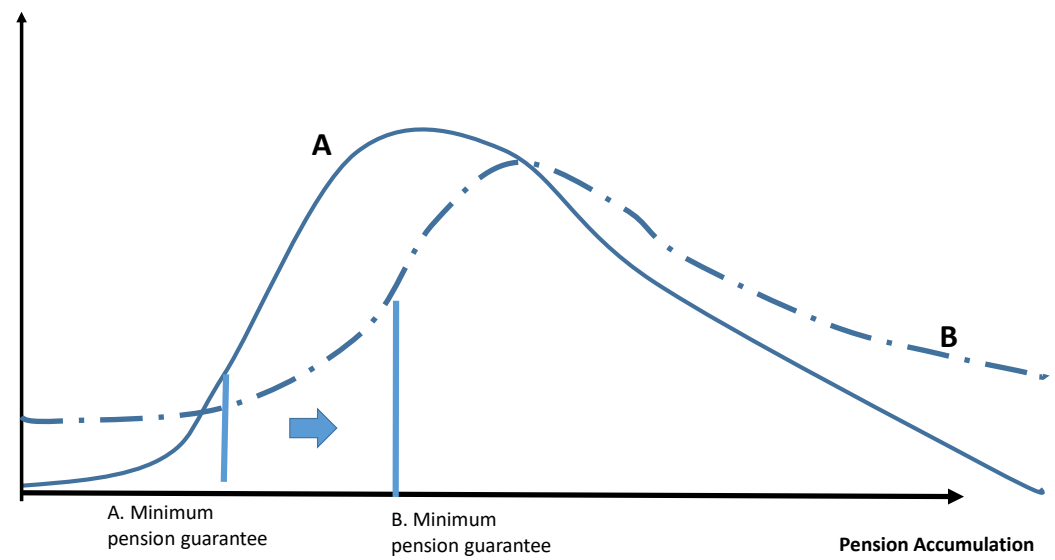

Figure 2. Income Distribution and the Minimum Pension Guarantee Level.

F. Average Age

In line with the Black-Scholes pricing model, the value of the put option decreases when the exercise date approaches. Therefore, it is determined that there is a negative correlation between the average dependency ratio in society and the total guarantee cost at a given point in time.

Table 1 summarizes the correlation between the guarantee cost and the above parameters.

Table 1. Influence on Guarantee Cost.

\begin{tabular}{cc}
\hline Parameter & Correlation \\
\hline The guarantee line & $?$ \\
\hline The funded pillar's size & \\
\hline The market's rate of return & \\
\hline GDP per capita rate of return
\end{tabular}

\section{Discussion}

Pension reversals have accelerated in recent years, mainly since the 2008 crisis and the recent COVID-19 financial crisis (Fultz and Hirose 2019; Gerard et al. 2020; Wolf and Caridad y Lopez Del Rio 2021b). As there are different reasons for the evolution of the pension in each country, global experience confirms that the demand for redistribution mechanisms or a minimum pension guarantee are common motives in the latest design of pension reforms around the globe. These mechanisms can address the form of pension top-ups, such as those in Argentina and Poland, or, for instance, a zero pillar in places such as Chile, Hungary, and Kazakhstan (Borzutzky and Hyde 2016).

The model introduced above argues that the question of pension reform sustainability is linked to the economic gain/loss of participants and not necessarily to the rate of return and the population coefficient growth, as was the case in the traditional economy research (Aaron 1966). The model asserts that the Aaron-Samuelson rule is valid in an economy with identical consumers or, at least, almost homogenous savers. In reality, the question of pension reform depends on statistical/political considerations. According to the above model, if a significant mass of participants will be negatively affected by the transition, the probability of reversal is higher. Accordingly, a financial crisis may result 
in political pressure to revert to more government intervention in the pension market. The option model above clearly shows that, economically, for low-earning cohorts whose old-age benefits are below the average, the replacement rate is negatively affected by the pension transition. According to the model above, The lower their average pensions accumulate below the former average replacement rate and/or the more the number of participants there are below the average replacement, the more the sustainability of the funded pension reform is at stake. To implement pension guarantee signals, all the earning cohorts must trust the pension system at retirement, despite the various risks of burden. According to this model, the central planner has to improve the financial benefit status of enough participants to maintain the pension scheme. Hence, the guarantee's strike price, if implemented, should be below the former average replacement rate.

To lower the guarantee cost, it was shown by the analog that to short put the option position, the central planner has to alleviate the level of inequality in society. Only then, can the guarantee strike price be increased and its cost be distributed among a larger group of participants.

\section{Conclusions}

This study analyzed old-age benefits during the transition from a DB PAYG pension scheme to a funded design. The results of the theoretical model demonstrate that the transition is beneficial, mainly for high-earning cohorts at the expense of low-earning cohorts. Moreover, implementing a minimum pension guarantee was revealed as an efficient way to increase the probability of the pension system's sustainability. The particular characteristics of the guarantee boundaries and their costs were studied in this research.

In addition to the public and the government, the traditional actors, we map another major actor-the individual. We claim that as a function of the income distribution in the market, the individual might gain political power and may influence the pension mechanism. Consequently, any pension scheme equilibrium must consider the individual interest. Individuals' financial position is not homogenous. Some benefit from the transition and some may lose. Seeking equilibrium in the funded pension scheme, we find two junctions of decisions. The first is at the public society level and the second is among different earning cohorts.

Moreover, in agreement with the emerging literature on pension reforms and rereforms, it was claimed that in a funded pension scheme, the central planner has an incentive to implement a minimum pension guarantee, avoiding cyclical pension reforms and fiscal risks while relying on unfunded pillars.

From this perspective, implementing the guarantee through intra-generational risk sharing can efficiently reduce the anomaly stated earlier. This kind of guarantee can be considered as a "collar" transaction, where the underlying asset is the total old-age benefit at retirement. Economically, this transaction compensates low earners for their lack of insurance against low benefits and high exposure to financial risks with a low ability to diversify them.

The theory introduced here follows the classic literature strand of consideration of funded and unfunded pension schemes and adds the dimension of risk and expectation of insurance as being key to sustainable schemes.

We find this study highly relevant in the current times when governments seek exit strategies from the Corona-virus pandemic-related financial crisis. Policymakers are moving somewhat beyond the narrow interpretation of pension system sustainability adopted in the previous decades. The link between the financial position of individuals and political pressure might be a novelty in the existing literature but has been proven true in the case of pension reversals in CEE countries and Latin America. Countries which implement funded pension schemes must ensure periodically that pension guarantee schemes are adequate and consistent with the income distribution level. Additionally, as financial and systemic shocks are accelerating public reaction, it will be interesting to examine the pension system design sometime after the corona-virus crisis. 
For further research, empirical analysis of the implementation of minimum guarantees in additional countries with different kinds of pension schemes is suggested. Specifically, it would be interesting to examine the inter-cohort balance in the notional defined contribution (NDC) form, which is increasing in popularity across Europe. Socio-economic research can be conducted in tandem with this paper by investigating the utility function of different cohorts while imposing a minimum pension guarantee.

Funding: The APC was funded by Ono Academic College, Tel Aviv.

Institutional Review Board Statement: Not applicable.

Informed Consent Statement: Informed consent was obtained from all subjects involved in the study.

Data Availability Statement: The Data can be found in the MDPI website.

Conflicts of Interest: The author declares no conflict of interest.

\section{Appendix A. High Funded Pension Schemes}

\begin{tabular}{|c|c|c|c|c|c|c|}
\hline State & $\begin{array}{l}\text { Dominanat Pension } \\
\text { Scheme (Accrual rate) }\end{array}$ & $\begin{array}{c}\text { average } \\
\text { replacement rate }\end{array}$ & Guarantee & Time Remarks & $\begin{array}{l}\text { Pension } \\
\text { Spending } \\
(\% \text { GDP) }\end{array}$ & $\begin{array}{c}\text { Pension } \\
\text { Funds } \\
\text { (\% GDP) }\end{array}$ \\
\hline Denmark & Mandatory occupational DC & $74 \%$ & High first tier. Minimum ( $36 \%$ AW) & High coverge in funded pension scheme & $8.1 \%$ & $58.40 \%$ \\
\hline U.S & DB $(0.91 \%)+D C$ & $\begin{array}{c}39.4 \% \\
\text { Full career-50\% }\end{array}$ & Basic & & $7 \%$ & $95.80 \%$ \\
\hline Switzerland & $\begin{array}{l}\text { Dominant DB+Mandatory } \\
\text { occupational DC }\end{array}$ & $\begin{array}{c}\quad 42.4 \% \\
\text { Full career- } 44 \%\end{array}$ & Minimum (22\% AW) & $\begin{array}{l}\text { High coverge in funded pension scheme. } \\
2019 \text { - increasing public pillar contributions } \\
\text { Risk for self employed. }\end{array}$ & $6.6 \%$ & $149.10 \%$ \\
\hline U.K & $\begin{array}{l}\text { Dominant DB (fixed benefit) } \\
\text { +Mandatory personal DC }\end{array}$ & $\begin{array}{c}21.7 \% \\
\text { Full career-30\% }\end{array}$ & Basic & $\begin{array}{l}\text { Funded-1993 } \\
50 \% \text { cpverage on funded pension schemes. }\end{array}$ & $5.6 \%$ & $118.50 \%$ \\
\hline Netherlands & $\begin{array}{l}\mathrm{DB}(1.75 \%+0.77 \% \mathrm{~B})+ \\
\text { Mandatory occupational DC }\end{array}$ & $\begin{array}{c}70.9 \% \\
\text { Full career- } 80 \%\end{array}$ & $\begin{array}{l}\text { Minimum (1250 Euro a month) + Social } \\
\text { Assitance }\end{array}$ & High coverge in funded pension scheme & $5.4 \%$ & $210.30 \%$ \\
\hline Canada & $\mathrm{DB}(0.63 \%+0.3 \% 5 \mathrm{~B})+\mathrm{DC}$ & $39 \%$ & $\begin{array}{l}\text { Mnimum }(32 \% \text { AW }) \\
\text { Social Assitance + Holistic model basic } \\
\text { pension }\end{array}$ & & $4.9 \%$ & $95.50 \%$ \\
\hline Australia & Mandatory occupational DC & $30.90 \%$ & $\begin{array}{l}\text { Minimum (Fltat rate) + Target }(27.7 \% \\
\text { AW) }\end{array}$ & High coverge in funded pension scheme & $4 \%$ & $128.70 \%$ \\
\hline Ireland & Mandatory personal DC & $\begin{array}{c}27 \% \\
\text { Full career }-35 \%\end{array}$ & Minimum (34\% AW) & $\begin{array}{l}\text { Less than } 60 \% \text { coverage in funded pension } \\
\text { schemes. }\end{array}$ & $3.70 \%$ & $34.40 \%$ \\
\hline Chile & Mandatory personal DC & $31.20 \%$ & Basic Social Assitance means tested & $\begin{array}{l}\text { Funded-1981; Reversal- } 2018 \\
\text { High coverage in funded pension schemes. }\end{array}$ & $2.8 \%$ & $75.80 \%$ \\
\hline Iceland & $\mathrm{DC}$ & $70 \%$ & Social Assitance & & $2.6 \%$ & $194.30 \%$ \\
\hline Mexico & $\mathrm{DB}+$ Mandatory personal DC & $25.70 \%$ & 2013 - Minimum (MW) & $\begin{array}{l}\text { Funded-1997; } \\
\text { High coverage in funded pension schemes. }\end{array}$ & $2.3 \%$ & $20.40 \%$ \\
\hline
\end{tabular}

\section{Note}

1 During the COVID-19 crisis, a global systemic risk was witnessed which includes a high unemployment rate and financial turmoil.

\section{References}

Aaron, Henry. 1966. The Social Insurance Paradox. Canadian Journal of Economics and Political Science 32: 371-74. [CrossRef]

Altiparmakov, Nikola. 2018. Another look at causes and consequences of pension privatization reform reversals in Eastern Europe. Journal of European Social Policy 28: 224-41. [CrossRef]

Antolín, Pablo, Stéphanie Payet, Edward Whitehouse, and Juan Yermo. 2011. The Role of Guarantees in Defined Contribution Pensions. In OECD Working Papers on Finance, Insurance and Private Pensions, No. 11. Paris: OECD Publishing. [CrossRef]

Barr, Nicholas, and Peter Diamond. 2009. Reforming pensions: Principles, analytical errors and policy directions. International Social Security Review 62: 5-29. [CrossRef]

Barr, Nicholas, and Peter Diamond. 2016. Reforming Pension in Chile. Polityka Społeczna Social Policy 1: 4-8.

Borzutzky, Silvia, and Mark Hyde. 2016. Chile's private pension system at 35: Impact and lessons. Journal of International and Comparative Social Policy 32: 57-73. [CrossRef] 
Chen, Damiaan H. J., Roel M. W. J. Beetsma, Eduard H. M. Ponds, and Ward E. Romp. 2014. Intergenerational Risk-Sharing Through Funded Pensions and Public Debt. Journal of Pension Economics and Finance 15: 127-59. [CrossRef]

Ebbinghaus, Bernhard. 2015. The Privatization and Marketization of Pensions in Europe: A Double Transformation Facing the Crisis. European Policy Analysis 1: 56-73. [CrossRef]

Ebbinghaus, Bernhard. 2019. Multi-Pillarization Remodelled: The Role of Interest Organizations in British and German Pension Reforms. Journal of European Public Policy 26: 521-39. [CrossRef]

Feldstein, Martin, and Elena Ranguelova. 2001. Individual Risk in an Investment-Based Social Security System. The American Economic Review 91: 1116-25. [CrossRef]

Fultz, Elaine, and Kenichi Hirose. 2019. Second-pillar Pensions in Central and Eastern Europe: Payment Constraints and Exit Options. International Social Security Review 72: 3-22. [CrossRef]

Gerard, François, Clément Imbert, and Kate Orkin. 2020. Social Protection Response to the COVID-19 Crisis: Options for Developing Countries. Oxford Review of Economic Policy 36: S281-96. [CrossRef]

Giorno, Claude, and Jacques Adda. 2016. Improving the Pension System and the Welfare of Retirees in Israel. OECD Working Paper No. 1288. Paris: OECD Publishing.

Grande, Giuseppe, and Ignazio Visco. 2010. A Public Guarantee of a Minimum Return to Defined Contribution Pension Scheme Members. The Journal of Risk 13: 3-43. [CrossRef]

Grech, Aaron G. 2015. Convergence or divergence? How the financial crisis affected European pensioners. International Social Security Review 68: 43-62. [CrossRef]

Guardiancich, Igor, and Mattia Guidi. 2020. The political economy of pension reforms in Europe under financial stress. Socio-Economic Review, mwaa012. [CrossRef]

Holzmann, Robert, and Richard Paul Hinz. 2005. Old-Age Income Support in the 21st Century: An International Perspective on Pension Systems and Reform. Washington, DC: The World Bank. [CrossRef]

Hujo, K., and M. Ralli. 2014. The Political Economy of Pension Re-Reform: Toward More Inclusive Protection. Geneva: United Nations Research Institute for Social Development, Social Policy and Development (2000-2009).

Jensen, Svend E. Hougaard, Torben Möger Pedersen, and Tove Birgitte Foxman. 2019. Experiences with Occupational Pensions in Denmark. Quarterly Journal of Economic Research 88: 11-30.

Mercer Global Pension Index. 2021. Available online: https://www.mercer.com/our-thinking/global-pension-index-2021.html\# contactForm (accessed on 10 July 2021).

Naczyk, Marek, and Stefan Domonkos. 2016. The Financial Crisis and Varieties of Pension Privatization Reversals in Eastern Europe. Governance 29: 167-84. [CrossRef]

Natali, David. 2018. Recasting Pensions in Europe: Policy Challenges and Political Strategies to Pass Reforms. Swiss Political Science Review 24: 53-59. [CrossRef]

Nelson, Kenneth, Rense Nieuwenhuis, and Susanne Alm. 2019. Sweden: Adjoining the Guarantee Pension with NDC. Social Protection Discussion Papers and Notes from The World Bank. Washington, DC: The World Bank.

OECD. 2019. Pensions at a Glance 2019: OECD and G20 Indicators. Paris: OECD Publishing. [CrossRef]

Orenstein, Mitchell A. 2013. Pension Privatization: Evolution of a Paradigm. Governance 26: 259-81. [CrossRef]

Pennacchi, George G. 1999. The value of guarantees on pension fund returns. Journal of Risk and Insurance 66: 219-37. [CrossRef]

Romaniuk, Katarzyna. 2009. The Options Embedded within Pension Plans: Types, Valuation Principles and Effects on Optimal Investment Policies. Bankers, Markets \& Investors, Forthcoming. Available online: https:/ / ssrn.com/abstract=1618324 (accessed on 10 July 2021).

Wolf, Ishay, and Jose Maria Caridad y Ocerin. 2021. The transition to a multi-pillar pension system: The inherent socio economic anomaly. Journal of Financial Economic Policy. [CrossRef]

Wolf, Ishay, and Lorena Caridad y Lopez Del Rio. 2021a. Funded-capitalized pension designs and the demand for minimum pension guarantee. Public and Municipal Finance 10: 12-24. [CrossRef]

Wolf, Ishay, and Lorena Caridad y Lopez Del Rio. 2021b. Pension Reforms and Risk Sharing Cycle: A Theory and Global Experience. International Journal of Economics \& Business Administration (IJEBA) 9: 225-42. 